\title{
28-Day Repeated Oral Toxicity Study and Efficacy of a Siddha Polyherbal Formulation - Singinatha Choornam against Platelet Activating Factor-induced Rhinosinusitis in Wistar Albino Rat
}

\author{
S. ELANSEKARAN ${ }^{*}$, V. GEETHA ${ }^{1}$, V. THANIGAVELAN ${ }^{2}$, M. RAMAMURTHY, V. KALIYAMURTHI ${ }^{3}$ AND P. PATHIBAN ${ }^{4}$
}

Department of Noi Naadal, National Institute of Siddha, Tambaram Sanatorium, Chennai-600 047, ${ }^{1}$ ESI Dispensary, Sriperumpudhur, Kanchipuram-602 105, 2Sairam Advanced Centre for Research, Sri Sairam Siddha Medical College and Research Centre, Chennai-600 044, '3epartment. of Basic Science, Fisheries College and Research Institute, Thoothukudi-628 008, 'irectorate of Indian Medicine and Homoeopathy, Arumbakkam, Chennai-600 106, India

\section{Elansekaran, et al.: Singinatha Choornam for Rhinosinusitis}

\begin{abstract}
Singinatha choornam is an oral polyherbal formulation used in the treatment of allergic rhinosinusitis cited in Siddha literature Agathiar Attavanai Vagadam. This study aimed to validate Singinatha choornam as an effective drug against platelet activating factor-induced rhinosinusitis in rat model. Safety study for Singinatha choornam was done by treating rats orally with 18,90 and $180 \mathrm{mg} / \mathrm{kg}$ b.wt./p.o./day for 28 days following OECD 407 guidelines. No mortality, abnormal signs and symptoms, significant haematological, biochemical and histopathological variations were observed. A phospholipid inflammatory mediator, $50 \mu 1$ were applied intranasally in rats of test and standard groups while control groups intranasally treated with $50 \mu$ of distilled water as single application. Three groups of rat were allotted (control - distilled water $2 \mathrm{ml} / \mathrm{dose}$, test drug Singinatha choornam $90 \mathrm{mg} / \mathrm{kg}$ and standard - chloropheniramine maleate $1 \mathrm{mg} / \mathrm{kg}$ ) and treated for 3 days. After end of the study, rats were sacrificed and examined for nasal sinuses and lamina propria histology. The count of neutrophils was reduced significantly in test group compared with control along absence of eosinophil. The study concluded that Singinatha choornam has efficacy against rhinosinusitis in rat model but not so significant to standard treatment.
\end{abstract}

Key words: Singinatha choornam, rhinosinusitis, repeated oral toxicity, herbal drug, Siddha medicine.

Agathiyar Rathinachurukka Naadi, an ancient literature of Siddha system of medicine listed 4448 diseases affecting the mankind ${ }^{[1]}$. Among them, diseases pertaining to the nasal region are ten. Mookku Neer Paaichal, a pathological term of one among nasal diseases cited in Siddha literature Nagamuni Sirarogavidhi having similar signs and symptoms of allergic rhinosinusitis such as sneezing, nasal itching and watery discharge, redness of eye, mild fever and head ach and also having same allergic etiology ${ }^{[2]}$.

In Siddha, various treatment modalities are mentioned including external therapies such as Pugai (fumigation), Patru (poultice), Viyarvai pidithal (medicated steam exposure), Nasiyam (nasal drops), Thylam (medicated oil) for oil bath and internal medicines such as Vasantha kusumagaram and Kasthuri Karuppu (herbometallic preparations). Agathiyar Attavanai Vagadam, a Siddha literature mentioned a polyherbal powder formulation Singinatha choornam (SC) as internal medicine for treating Mookku Neer Paaichal (rhinosinusitis) at one gram dosage with hot water ${ }^{[3]}$. The herbal ingredients present in the SC are Chukku (dried rhizome of
Zingiber officinale Roscoe), Milagu (dried fruit of Piper nigrum Linn), Thippili (dried fruit of Piper longum Linn), Karkadaga Shingi (gall of Rhus succedanea Linn), Katthiri ver (root of Solanum melongena Linn) and Kandankatthiri ver thol (root cortex of Solanum surattense Burm) in equal proportion. The method of preparation of SC was already noted in our previous study ${ }^{[4]}$. The analytical quality testing including thin layer chromatography study and antimicrobial analyses were done in our previous work has been reported ${ }^{[4]}$. The safety profile of each ingredient in this poly herbal formulation was already studied in animal model and has been reported. In human, SC can be administered for rhinosinusitis for the period up to 7 days. So, the present work investigated the subacute toxicity of SC on administering as repeated dose orally for 28 days since to rule whether it might produce toxicity on combining the each ingredient. Further to validate its efficacy against rhinosinusitis as mentioned under its therapeutic indication, the study was done in allergic rhinosinusitis rat model induced by platelet activating factor (PAF). PAF is a phospholipid activator which mediates inflammatory response in allergic reactions ${ }^{[5]}$. On intranasal application of PAF in rodents, it causes allergic inflammation in 
the nasal and paranasal sinus mucosa and mimics the same pathology of allergic rhinosinusitis in human ${ }^{[5]}$. PAF-induced rhinosinustis model was adopted for the validation of the efficacy of SC in rat model.

\section{MATERIALS AND METHODS}

Singinatha choornam (SC) was previously prepared by the method described in Agathiyar Attavanai Vagadam $^{[3,4]}$. Platelet activating factor- 16 (PAF-16 $\mu \mathrm{g} / \mathrm{ml}$ ) was purchased from Sigma Aldrich. Ketamine and Xylazine $\mathrm{HCl}$ injections were purchased from Sun Pharma Ltd and Indian Immunologicals Ltd, India respectively. Phenobarbitol sodium injection was purchased from Samarth Pharma Pvt Ltd.

\section{Experimental animals:}

Healthy out-bred male and female Wistar albino rats (100-150 g) were obtained from the animal house of King Institute of Preventive Medicine, Guindy, Chennai and maintained in the animal laboratory of Sairam Advanced Centre for Research, Chennai. The animals were housed in Polypropylene cages provided with bedding of husk. All the animals were kept under standard environmental condition $\left(23 \pm 2^{\circ}\right)$ with well-ventilated condition of $12 / 12 \mathrm{~h}$ dark and light cycle. The animals had free access to water and standard pellet diet (Sri Venkateshwara Traders, Bangalore). All the animals were acclimatized for 7 days prior to the study. Animal Guidelines of CPCSEA, Ministry of animal Husbandry and welfare, Govt. of India were strictly followed of the care and maintenance of procured animals. The study was approved by Institutional Animal Ethical Committee (IAEC), Sairam Advanced Centre for Research, Chennai, India.

\section{Study design for 28-days repeated oral dose toxicity:}

The study was performed following Organization for Economic Cooperation and Development (OECD) guideline $407^{[6]}$. On the basis of result of acute oral toxicity study of SC done under OECD 423 guideline, three doses of $18 \mathrm{mg} / \mathrm{kg}$ (low dose), $90 \mathrm{mg} / \mathrm{kg}$ (intermittent dose) and $180 \mathrm{mg} / \mathrm{kg}$ (high dose) were selected for the study ${ }^{[4]}$. All the animals were randomized accordingly with their body weights into 4 groups of 10 animals each (5 males, 5 females/group). Group I served as control which received distilled water at $2 \mathrm{ml} / \mathrm{kg}$ orally. Group II, III and IV received test doses of 18, 90 and $180 \mathrm{mg} /$ $\mathrm{kg}$, respectively of SC suspended in $2 \mathrm{ml}$ of distilled water for a period of 28 days through gastric cannula.

All experimental animals were observed twice daily for general behavior, respiratory pattern, cardiovascular signs, motor activity, reflexes, changes in skin, fur and mortality. All rats were weighed weekly and observed for food and water intake weekly. On $28^{\text {th }}$ day of the experiment, $24 \mathrm{~h}$ urine samples were collected by placing the survived animals in the metabolic cage with free access to tap water but no feed was given. The urine was freed from fecal contamination. Toluene is used as a preservative while collecting the sample. The sediments present in the urine were removed by centrifugation and the collected urine was used for biochemical estimations. On $29^{\text {th }}$ day, the animals were fasted for approximately $18 \mathrm{~h}$ and then slightly anaesthetized with $\mathrm{CO}_{2}$ and blood samples were collected by cardiac puncture into two tubes with EDTA for immediate analysis of haematological parameters and without any anticoagulant for analysis of biochemical parameters. Blood without anticoagulant was centrifuged at $4000 \mathrm{rpm}$ at $4^{\circ}$ for 10 min to obtain serum. Serum was stored at $-20^{\circ}$ until analysed for biochemical parameters. Blood samples of control and experimental rats was analysed for haemoglobin content, total red blood corpuscles (RBC) and white blood corpuscles (WBC) count, differential WBC count, platelet content and packed cell volume (PCV) by routine procedures. Serum of control and experimental rats were analysed for protein, albumin, urea, blood urea nitrogen (BUN), creatinine, bilirubin, triglycerides, cholesterol and glucose levels was carried using standard methods. Activities of glutamate oxaloacetate transaminase/ aspartate aminotransferase (GOT/AST), glutamate pyruvate transaminase/alanine amino transferase (GPT/ALT) and alkaline phosphatase were estimated as per the colorimetric procedure. Sodium and potassium level was estimated using flame photometer. Necropsy of all sacrificed animals was carried out and weight of the organs includes liver, kidneys, spleen, brain, heart and lungs weights were recorded. Histopathological investigation of the vital organs such as liver, spleen, heart and kidney was done on control and SC high test dose group. The organ pieces (3-5 $\mu \mathrm{m}$ thick) of the highest dose level of $180 \mathrm{mg} / \mathrm{kg}$ were preserved and were fixed in $10 \%$ formalin for $24 \mathrm{~h}$ and washed in running water for 24 h. Samples were dehydrated in an auto-technicon and then cleared in benzene to remove absolute alcohol. Embedding was done by passing the cleared samples through three cups containing molten paraffin at $50^{\circ}$ and then in a cubical block of paraffin made by the "L" moulds. It was followed by microtome and the slides were stained with Haematoxylin-Eosin. The 
sections were examined under light microscope at $\times 40$ magnification.

\section{Induction of rhinosinusitis:}

The rats were randomly selected and sedated with ketamine $\mathrm{HCl}(75 \mathrm{mg} / \mathrm{kg}$ b.wt) and xylazine $\mathrm{HCl}$ $(10 \mathrm{mg} / \mathrm{kg})$. PAF $(50 \mu \mathrm{l})$ was applied into the nasal cavities as nasal drops in each naris (intra nasally) as single administration ${ }^{[7]}$. After application PAF, animals were divided into three groups with six animals in each group. Group I was considered as vehicle control and received distilled water $2 \mathrm{ml} / \mathrm{po}$ for 3 days. Group II was considered as standard and received $1 \mathrm{mg} / \mathrm{kg}$ of Chloropheniramine maleate for 3 days orally. Group III was considered as test group and received $90 \mathrm{mg} / \mathrm{kg}$ of Singinatha choornam suspended in $2 \mathrm{ml}$ of distilled water. The absolute dose of test drug given to the rat was calculated by the body surface area ratio between human intended dosages against rat $^{[8]}$.

After three days of treatment, all rats were sacrificed painlessly by phenobarbitol injection (120 mg/ $\mathrm{kg}$ ). Each head was decapitated and immersed in formalin. Eyes, skin and muscle were stripped from the head and mandibles were excised. The remaining specimens were decalcified for softness in 0.25 $\mathrm{M}$ EDTA in phosphate buffer (PB, pH 7.2). The specimens were excised from a plane posterior to the incisor to a plane anterior to the first molar and the middle segments were taken out. These segments were washed in PB and cut into $10 \mu \mathrm{m}$ thick sections using microtome from posterior to anterior including midline septum, upper naso turbinate, lower maxilla turbinate and maxillary sinus and were stained with hematoxyline and eosin (H-E). The appearance of clusters of inflammatory cells in sinuses was observed under light microscope. The ratio of the number of sinus spaces occupied by inflammatory cell clusters to the total number of sinus spaces of the histological slides was determined. The number of inflammatory cells infiltrating the lamina propria was counted at $\times 100$ magnification from mucosal sampling areas such as lateral sinus wall, upper and lower septa, upper naso turbinate and lower maxillo turbinate on both sides. The count was determined for each of three sections per rat.

\section{Statistical analysis:}

All the values were expressed as mean \pm standard error of mean (SEM). All the groups were compared and tested for significance using one way ANOVA followed by Dunnett's post hoc analysis and TukeyKramer multiple comparison test using Graph Pad Instat Version 3 software programme. Values of $\mathrm{P}<0.05$ were considered significant.

\section{RESULTS}

During 28 days repeated oral toxicity study of Singinatha choornam (SC) at varying doses of 18, 90 and $180 \mathrm{mg} / \mathrm{kg}$ administered daily, no mortality was observed. The result of Table 1 shows no significant differences in mean organ weight between the control and SC treated animals after 28 days. The mean body weight gained of control group after 28 days treated with distilled water was $10.95 \mathrm{~g}$. In test groups treated at doses of 18,90 and $180 \mathrm{mg} / \mathrm{kg}$, the mean body weight gained were $7.01,3.8$ and $5 \mathrm{~g}$, respectively (Table 2). No significant differences in weekly mean body weight between control and test groups were observed (Table 2). Food and water consumption of $\mathrm{SC}$ treated rats were same as control. The Table 3 shows the effect of SC having no significant impact on hematological parameters in rats after 28 days

TABLE 1: MEAN ORGAN WEIGHT OF RATS AFTER 28 DAYS TREATMENT WITH SINGINATHA CHOORNAM

\begin{tabular}{ccccccc}
\hline Treatment $(\mathrm{mg} / \mathrm{kg})$ & Liver $(\mathrm{g})$ & Heart $(\mathrm{g})$ & Lung $(\mathrm{g})$ & Spleen $(\mathrm{g})$ & Brain $(\mathrm{g})$ & Kidney $(\mathrm{g})$ \\
\hline Control & $5.24 \pm 0.14$ & 0.700 .05 & $1.78 \pm 0.25$ & $0.74 \pm 0.07$ & $1.43 \pm 0.18$ & $0.70 \pm 0.05$ \\
18 & $6.3 \pm 0.24$ & $0.65 \pm 0.12$ & $2.12 \pm 0.42$ & $0.82 \pm 0.17$ & $1.6 \pm 0.41$ & $0.81 \pm 0.11$ \\
90 & $6.4 \pm 0.3$ & $0.72 \pm 0.11$ & $2.2 \pm 0.8$ & $1.1 \pm 0.08$ & $1.65 \pm 0.36$ & $0.92 \pm 0.09$ \\
180 & $5.8 \pm 0.62$ & $0.76 \pm 0.04$ & $1.96 \pm 0.56$ & $0.94 \pm 0.03$ & $1.52 \pm 0.13$ & $0.76 \pm 0.04$ \\
\hline
\end{tabular}

Values are expressed as mean $\pm S E M ; n=10$, no significant changes observed among the groups

TABLE 2: MEAN BODY WEIGHT OF RATS AFTER 28 DAYS TREATMENT WITH SINGINATHA CHOORNAM

\begin{tabular}{cccccc}
\hline Treatment (mg/kg) & \multicolumn{5}{c}{ Weekly mean body weight (g) } \\
\cline { 2 - 6 } & Day 1 & Day 7 & Day 14 & Day 21 & Day 28 \\
\hline Control & $122.37 \pm 3.21$ & $124.14 \pm 4.09$ & $128.21 \pm 2.17$ & $129.21 \pm 5.11$ & $133.32 \pm 1.89$ \\
18 & $125.21 \pm 3.25$ & $128.12 \pm 3.41$ & $128.17 \pm 2.71$ & $127.17 \pm 2.71$ & $132.22 \pm 3.54$ \\
90 & $129.45 \pm 3.65$ & $132.25 \pm 2.14$ & $132.25 \pm 3.42$ & $132.25 \pm 3.42$ & $133.25 \pm 2.34$ \\
180 & $128.45 \pm 3.75$ & $132.45 \pm 2.34$ & $132.48 \pm 3.25$ & $132.48 \pm 3.25$ & $133.45 \pm 3.25$ \\
\hline
\end{tabular}

Values are expressed as mean $\pm \mathrm{SEM} ; \mathrm{n}=10$, no significant changes observed among the groups 
treatment. The result of biochemical study (Table 4) shows significant $(\mathrm{P}<0.05)$ increase in SGPT level at all three doses of SC and at high dose $(180 \mathrm{mg} / \mathrm{kg})$ significant $(\mathrm{P}<0.05)$ increase in Alkaline phosphatase was inferred. No significant differences between the control and the animals treated with SC in other biochemical parameters tested were observed (Table 4). Urine analysis data (Table 5) of control and treated groups determined on $28^{\text {th }}$ day did not reveal major abnormalities except in transparency and deposits of epithelial cells at high dose. Gross necropsy of organs examined immediately after dissection on $29^{\text {th }}$ day shows no gross pathological lesions. Histological examination of liver, spleen, heart and kidney treated on high dose of SC $(180 \mathrm{mg} / \mathrm{kg})$ exhibit no apparent pathological alterations compared to control (fig 1). No abnormality is seen in hepatocytes, sinusoids, trabeculae, capsule of spleen, nuclei of myocytes, myocardium, glomeruli, Bowman's capsule and capillaries treated on high dose. The lowest-observed adverse effect level (LOAEL) of SC is seen in high

TABLE 3: EFFECT OF 28 DAYS TREATMENT OF SINGINATHA CHOORNAM ON HAEMATOLOGICAL PARAMETERS IN RATS

\begin{tabular}{ccccc}
\hline Parameter & Control & $\mathbf{1 8}(\mathbf{m g} / \mathbf{k g})$ & $\mathbf{9 0}(\mathbf{m g} / \mathbf{k g})$ & $\mathbf{1 8 0}(\mathbf{m g} / \mathbf{k g})$ \\
\hline RBC $\left(\times 10^{6} / \mathrm{mm}^{3}\right)$ & $7.51 \pm 0.16$ & $7.22 \pm 0.14$ & $6.37 \pm 0.25$ & $6.47 \pm 0.23$ \\
PCV (\%) & $48.2 \pm 1.3$ & $46.4 \pm 2.6$ & $41.2 \pm 3.2$ & $43.6 \pm 1.2$ \\
Hb (\%) & $15.6 \pm 0.19$ & $15.3 \pm 0.3$ & $14.6 \pm 1.2$ & $14.8 \pm 0.8$ \\
WBC $\left(10^{3} / \mathrm{mm}^{3}\right)$ & $10.12 \pm 1.2$ & $11.2 \pm 1.4$ & $11.6 \pm 2.1$ & $12.5 \pm 1.3$ \\
Neutrophils (\%) & $22.0 \pm 4.0$ & $24.4 \pm 2.2$ & $25.2 \pm 3.1$ & $28.3 \pm 1.2$ \\
Mononuclear cells (\%) & $76.0 \pm 2.0$ & $74.2 \pm 1.4$ & $73.8 \pm 1.6$ & $71.2 \pm 0.8$ \\
Eosinophils (\%) & $2.4 \pm 0.6$ & $2.2 \pm 0.3$ & $1.4 \pm 0.6$ & $1.1 \pm 0.28$ \\
Platelets $\left(\times 10^{3} / \mathrm{mm}^{3}\right)$ & $423.2 \pm 48.8$ & $451.4 \pm 42.3$ & $443.6 \pm 36.9$ & $425 \pm 33.2$ \\
\hline
\end{tabular}

Values are expressed as mean $\pm S E M ; n=10$, no significant changes observed among the groups

TABLE 4: EFFECT OF 28 DAYS TREATMENT OF SINGINATHA CHOORNAM ON SERUM BIOCHEMICAL PARAMETERS IN RATS

\begin{tabular}{|c|c|c|c|c|}
\hline Parameter & Control & $18 \mathrm{mg} / \mathrm{kg}$ & $90 \mathrm{mg} / \mathrm{kg}$ & $180 \mathrm{mg} / \mathrm{kg}$ \\
\hline Protein (g/dl) & $8.62 \pm 1.3$ & $9.37 \pm 2.48$ & $10.41 \pm 4.32$ & $10.47 \pm 4.35$ \\
\hline Albumin (g/dl) & $4.8 \pm 0.6$ & $4.32 \pm 1.2$ & $5.2 \pm 1.3$ & $5.3 \pm 0.8$ \\
\hline BUN (mg/dl) & $19.2 \pm 1.2$ & $21.2 \pm 3.2$ & $18.4 \pm 1.2$ & $17.6 \pm 2.1$ \\
\hline Urea (mg/dl) & $64.24 \pm 3.11$ & $67.32 \pm 3.12$ & $69.12 \pm 4.12$ & $69.13 \pm 2.32$ \\
\hline Creatinine $(\mathrm{mg} / \mathrm{dl})$ & $0.82 \pm 0.16$ & $0.63 \pm 0.14$ & $1.19 \pm 1.42$ & $1.28 \pm 0.31$ \\
\hline Total Cholesterol(mg/dl) & $91.24 \pm 1.35$ & $92.79 \pm 2.14$ & $93.84 \pm 1.32$ & $93.71 \pm 1.96$ \\
\hline Triglycerides(mg/dl) & $50.15 \pm 3.21$ & $57 \pm 3.4$ & $52.4 \pm 4.2$ & $56.4 \pm 5.6$ \\
\hline Glucose (mg/dl) & $110.16 \pm 8.62$ & $120 \pm 1.35$ & $122.37 \pm 5.23$ & $123.34 \pm 2.07$ \\
\hline Total Bilirubin (mg/dl) & $0.205 \pm 0.04$ & $0.212 \pm 0.06$ & $0.216 \pm 0.02$ & $0.4 \pm 0.02$ \\
\hline SGOT (U/I) & $73 \pm 2.4$ & $78 \pm 4.1$ & $86.2 \pm 3.2$ & $85.3 \pm 4.6$ \\
\hline SGPT(U/I) & $28.4 \pm 1.2$ & $46.4 \pm 3.2^{*}$ & $39.4 \pm 4.6^{*}$ & $42.5 \pm 2.2^{*}$ \\
\hline Alkaline phosphatase (U/I) & $102.4 \pm 3.6$ & $92.8 \pm 4.6$ & $114.3 \pm 4.2$ & $82.4 \pm 3.4^{*}$ \\
\hline Sodium $(\mathrm{mEq} / \mathrm{l})$ & $138.12 \pm 3.14$ & $142.6 \pm 5.32$ & $128.4 \pm 6.2$ & $146.3 \pm 1.2$ \\
\hline
\end{tabular}

Values are expressed as mean $\pm S E M ; n=10$. ANOVA with post hoc Dunnett test, ${ }^{*} \mathrm{P}<0.05$ vs control

TABLE 5: EFFECT OF 28 DAYS TREATMENT OF SINGINATHA CHOORNAM ON URINE PARAMETERS IN RATS

\begin{tabular}{|c|c|c|c|c|}
\hline Parameter & Control & $18(\mathrm{mg} / \mathrm{kg})$ & 90 (mg/kg) & $180(\mathrm{mg} / \mathrm{kg})$ \\
\hline Colour & Yellow & Yellow & Yellow & Yellow \\
\hline Transparency & Clear & Clear & Turbid & Turbid \\
\hline Specific gravity & 1.01 & 1.02 & 1.04 & 1.05 \\
\hline $\mathrm{pH}$ & 7.2 & 7.4 & 6.9 & 7.3 \\
\hline Protein & Nil & Nil & Nil & Nil \\
\hline Glucose & Nil & Nil & Nil & Nil \\
\hline Bilirubin & -ve & -ve & -ve & -ve \\
\hline Ketones & -ve & -ve & -ve & -ve \\
\hline Blood & Absent & Absent & Absent & Absent \\
\hline RBCs & Nil & $\mathrm{Nil}$ & Nil & $\mathrm{Nil}$ \\
\hline Epithelial cells & Nil & Nil & Nil & occasional \\
\hline Casts & Nil & Nil & Nil & $\mathrm{Nil}$ \\
\hline
\end{tabular}



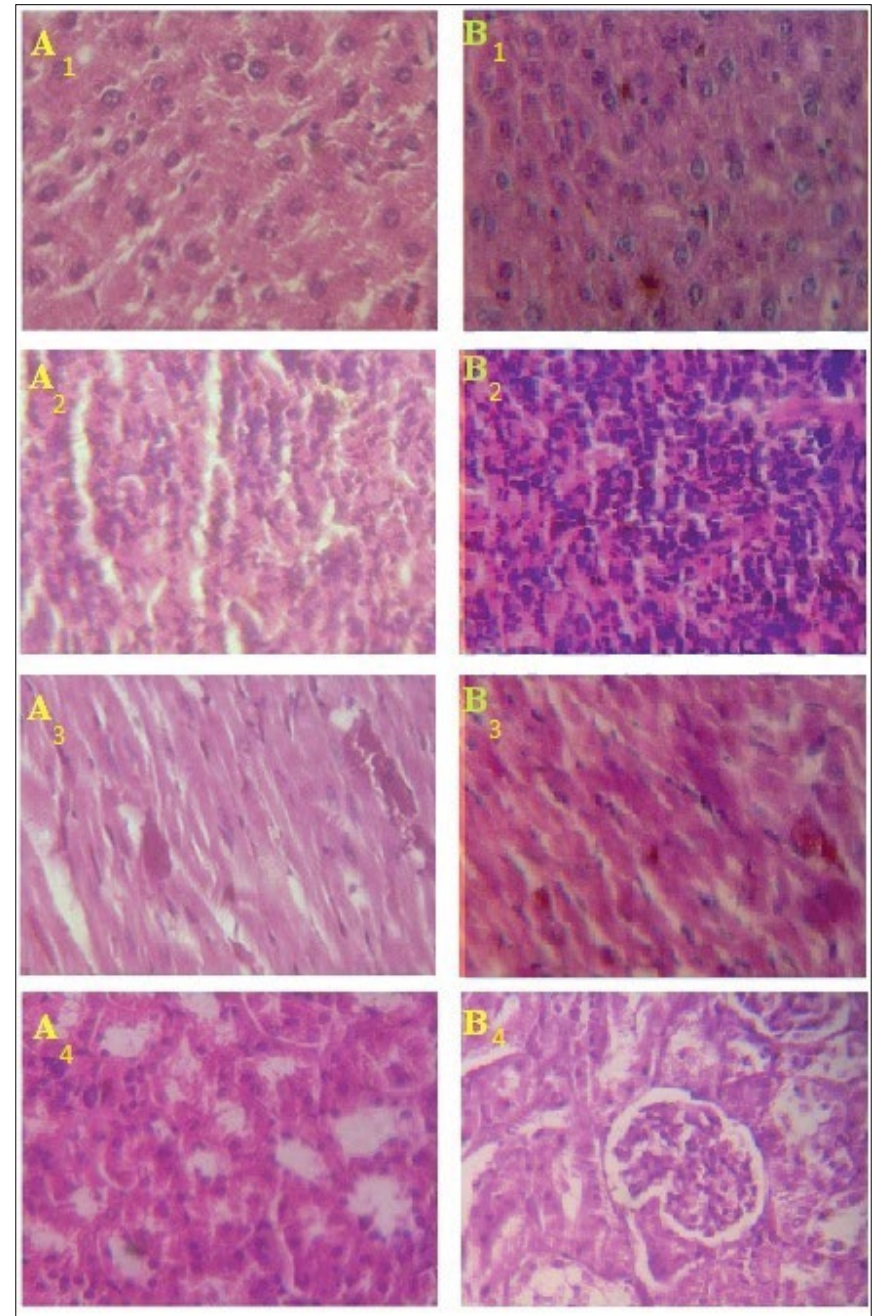

Fig. 1: Histopathological study of vital organs.

Histopathological study of vital organs in rats - control and high dose group (Hematoxylin-eosin, $\times 40$ ). A1, A2, A3 and A4liver, spleen, heart and kidney sections of control rat respectively. B1-liver section treated with SC at $180 \mathrm{mg} / \mathrm{kg} \mathrm{shows} \mathrm{no}$ abnormality in hepatocytes and sinusoids, B2-spleen section treated with SC at $180 \mathrm{mg} / \mathrm{kg}$ shows no abnormality in trabeculae and capsule, B3-heart section treated with $\mathrm{SC}$ at $180 \mathrm{mg} / \mathrm{kg}$ shows no abnormality in nuclei of myocytes and myocardium, B4kidney section treated with SC at $180 \mathrm{mg} / \mathrm{kg}$ shows no abnormality in glomeruli and Bowman's capsule, capillaries

dose $(180 \mathrm{mg} / \mathrm{kg})$ group and no-observed adverse effect level (NOAEL) of SC range between 18 to 90 $\mathrm{mg} / \mathrm{kg}$.

The results of Table 6 show the effect of SC against PAF-induced rhinosinusitis in rat. The ratio of the sinus spaces occupied by neutrophil clusters and infiltration of neutrophils in lamina propria observed extensively in control rats. The ratio of the sinus spaces occupied by neutrophil clusters and infiltration of neutrophils in lamina propria observed significantly reduced $(\mathrm{P}<0.05)$ in both standard and test drug treated group. The test group was not so much significant while comparing with standard group. The histological evidences of rhinosinusitis such as the appearance of neutrophil clusters in the air space and infiltration of neutrophils in the lamina propria were extensively observed in control rats. H-E staining revealed evidence of reduction of inflammatory cell clusters in the sinonasal air spaces bounded by the septum, upper naso-turbinate and lower maxillo-turbinate in the sections obtained from standard and test drug treated rats.

\section{DISCUSSION}

In our earlier studies on SC, the acute oral toxicity study conducted on rat at the highest starting dose level of $2000 \mathrm{mg} / \mathrm{kg}$ body weight following OECD guidelines 423 revealed no mortality and no significant abnormal clinical observations ${ }^{[4]}$. This study revealed the median lethal dose value for SC has been estimated more than $2000 \mathrm{mg} / \mathrm{kg}$ body weight accordance to globally harmonised system of classification and labelling chemicals ${ }^{[4]}$. In our present studies, to establish its safety on cumulative toxicity, 28 day repeated oral toxicity experiment was performed. In the literature Agathiar Attavanai Vagadam, the human intended dosage for SC is cited as $1 \mathrm{~g} / \mathrm{dose}^{[3]}$. Based on surface body ratio between human and rat, three dosing level $(18,90$ and $180 \mathrm{mg} /$ $\mathrm{kg}$ ) of SC were assigned for 28 days treatment ${ }^{[8]}$. No 
TABLE 6: EFFECT OF SINGINATHA CHOORNAM AT 90 MG/KG AGAINST PLATELET ACTIVATING FACTOR INDUCED RHINOSINUSITIS IN RATS

\begin{tabular}{lccc}
\hline \multicolumn{1}{c}{ Observation } & Control group & Standard group & Test group \\
\hline Ratio of sinus spaces occupied by neutrophil clusters & $0.26167 \pm 0.01447$ & $0.055 \pm 0.00619^{*, \$}$ & $0.18167 \pm 0.00946^{*}$ \\
Neutrophils infiltration in the lamina propria & $118.167 \pm 3.371$ & $9.667 \pm 2.431^{*, \$}$ & $60.0 \pm 4.782^{*}$ \\
\hline
\end{tabular}

Values are expressed as mean \pm SEM; $n=6$. ANOVA with Tukey-Kramer multiple comparison test, $* P<0.05$ denotes significance against control group. ${ }^{\$} \mathrm{P}<0.05$ denotes significance between standard and test group

mortality and morbidity were recorded throughout the period for the three doses of SC. The feed and water consumption during the test period was not altered which indicate SC did not affect the carbohydrate, lipid and protein metabolism of rats ${ }^{[9]}$. All haematological parameters were within the normal limit reveal SC did not affect the production and not cause pathological variation in blood corpuscles ${ }^{[9]}$. To elucidate the toxicity produced during liver metabolism of drug, transaminase markers play a vital role. Among transaminases, SGPT significantly increased in three dosage groups and AP level was increased in high dose group on comparing with control groups but their values lie within normal limit. The histological section on liver shows normal architecture favour confirmation above inference. Urine parameters remain normal observation in all groups except urine transparency and deposits in high dosage group. The renal function test and other biochemical parameters were within the normal limit and normal renal histology favour SC does not involve in renal toxicity. Gross morphology and histological studies on major organs were in normal pattern providing supportive evidences for the observation got during haematological, biochemical and urine analyses. No significant changes were observed in the relative organ weights between control and SC treated rats. LOEL of SC is more than $180 \mathrm{mg} / \mathrm{kg}$ and it is free from producing cumulative poisoning on oral administration with in the dose of $180 \mathrm{mg} / \mathrm{kg}$.

PAF is an important inflammatory mediator of allergic rhinosinusitis which induce vascular leakage and lead to rhinorrhea formation and congestion ${ }^{[10]}$. For inducing rhinosinusitis in animal model, PAF is administered through nasal orifice which stimulates mast cell in nasal mucosa and increase the neutrophlis and eosinophils content ${ }^{[11]}$. On blocking PAF receptor, the efficacy against allergic rhinosinusitis of SC can be proved. In the study, after 3 days of treatment with SC at $90 \mathrm{mg} / \mathrm{kg}$ dose orally against single nasal application of PAF, H-E stained nasal sinuses and lamina propria revealed no evidence of accumulation of neutrophil cluster in the spaces, haemorrhage and epithelial damage. The evidence of absence of eosinophils and monocytes infiltration demonstrate SC has significant efficacy against acute neutrophilic inflammation since the presence of above cells will be last for more than 14 days indicate chronic rhinosinustis. It has been concluded that SC at $90 \mathrm{mg} / \mathrm{kg}$ body weight dose can be used safely in oral formulation and it is a PAF receptor antagonist for treating Allergic Rhinosinusitis by reducing inflammatory cells in nasal mucosa.

\section{FINANCIAL ASSISTANCE}

None.

\section{CONFLICT OF INTERESTS}

None declared.

\section{REFERENCES}

1. Shanmugavelu M, editor. Noinaadal Noi Mudal Naadal Thirattu. Part 2. 3rd edition, Chennai: Directorate of Indian medicine and Homeopathy; 2003.

2. Uthamarayan, editor. Aruvai Maruthuvam. 3rd edition, Chennai: Directorate of Indian medicine and Homeopathy; 2003.

3. Arangarajan S, editor. Agathiar Attavanai Vagadam. 1st edition, Tanjore: Saraswathy Mahal Library; 1991.

4. Geetha V, Elansekaran S, Thanigavelan V, Kaliyamurthi V, Parthiban P, Kanagavalli K. Evaluation of in vitro antibacterial activity and median lethal dose estimation of a siddha polyherbal formulation: Singinatha choornam in rat model. Int J Pharm Bio Sci 2015;6:236-41.

5. Edwards LJ, Constantinescu CS. Platelet activating factor/ platelet activating factor receptor pathway as a potential therapeutic target in autoimmune diseases. Inflamm Allergy Drug Targets 2009;8:182-90.

6. OECD Guidelines for the Testing of Chemicals (No. 407, Section 4: Health Effects) "Repeated Dose 28-Day Oral Toxicity in Rodents".

7. Kim JP, Kim EA, Jeon SY, Hwang EG. A Rat Model of Rhinosinusitis induced by Platelet Activating Factor (PAF). Korean J Otolaryngol Head Neck Surg 2000;44:712-17.

8. Bhardwaj S, Deepika Gupta. Study of acute, Sub acute and chronic toxicity test. Int J Adv Res Pharm Bio Sci 2012; 2:103-29.

9. Kesavanarayanan KS, Kalaivani P, Ramakrishnan G, Sathiya S, Ranju V, Jyothipriya R, et al. 28 Day Repeated Dose Oral Toxicity of a Herbal Mixture Dia-2 containing standardized extracts of Allium sativum and Lagerstroemia speciosa in Sprague Dawley Rats. Int J Phytomedicine 2012;4:340-50.

10. Garrelds M, de Graaf int Veld C, Gerth van Wijk R, Zijlstral FJ. Nasal hyper reactivity and inflammation in allergic rhinitis. Mediators Inflamm 1996;5:79-94.

11. Cano RM, Valero A, Izquierdo I, Lópe JS, Doménech A, Bartra J, et al. Evaluation of nasal symptoms induced by platelet activating factor, after nasal challenge in both healthy and allergic rhinitis subjects pretreated with rupatadine, levocetirizine or placebo in a cross-over study design. Allergy Asthma Clin Immunol 2013;9:43. 